\title{
PEMBERDAYAAN IBU RUMAH TANGGA DI KELURAHAN CINERE DALAM PENANAMAN DAN PEMANFAATAN TANAMAN OBAT KELUARGA (TOGA)
}

\author{
Putri Permatasari ${ }^{1}$ dan Fathinah Ranggauni Hardy ${ }^{2}$ \\ ${ }^{1}$ Universitas Pembangunan Nasional "Veteran" Jakarta \\ ${ }^{2}$ Universitas Pembangunan Nasional "Veteran" Jakarta \\ ppermatasari8@gmail.com, fathinahranggaunihardy@gmail.com
}

\begin{abstract}
ABSTRAK
Pemberdayaan ibu rumah tangga di Kelurahan Cinere dalam penanaman dan pemanfaatan TOGA salah satunya dapat digunakan untuk mendukung pemberdayaan Ibu Ibu PKK dengan pemanfataan lingkungan yang ada di wilayah tersebut. TOGA adalah tanaman hasil budidaya rumahan yang berkhasiat sebagai obat. Penanaman TOGA dapat di pot atau di lahan sekitar rumah, dan jika lahan yang ditanami cukup luas maka sebagian hasil panen dapat dijual dan menambah pendapatan keluarga. Adapun pemanfaatan TOGA selain sebagai obat, juga dapat dimanfaatkan untuk: (1) penambah gizi keluarga (pepaya, timun, bayam), (2) bumbu atau rempah-rempah masakan (kunyit, kencur, jahe, serai, daun salam), (3) menambah keindahan (mawar, melati, bunga matahari, kembang sepatu, tapak dara, kumis kucing). Kegiatan kemitraan masyarakat dilakukan pada Jumat, 7 September 2018 di Mushola Nurul Arifin RW. 12 Kel. Cinere Kec. Cinere Kota Depok. Kegiatan dilakukan dengan metode ceramah dan demonstrasi. Metode ceramah untuk menjelaskan tentang khasiat TOGA secara ilmiah, penanaman Tanaman Obat Keluarga (TOGA), dan pengolahan TOGA. Metode demonstrasi untuk mempraktekan penanaman Tanaman Obat Keluarga (TOGA). Kelurahan Cinere merupakan salah satu kecamatan yang berada di Kota Depok. Umumnya masyarakat di wilayah tersebut masih memiliki lahan pekarangan yang cukup luas, sehingga pemanfaatan dan pengelolaanemnas lingkungan dapat dioptimalkan dengan penanaman TOGA. Oleh karena itu perlu dilakukan pelatihan tentang khasiat TOGA secara ilmiah. Masyarakat yang telah memiliki pengetahuan tentang khasiat TOGA dan menguasai cara pengolahannya dapat membudidayakan tanaman obat secara individual dan memanfaatkannya sehingga akan terwujud prinsip kemandirian dalam pengobatan keluarga. Selain itu juga dapat dikembangkan menjadi usaha kecil dan menengah di bidang obat-obatan herbal, yang selanjutnya dapat disalurkan ke masyarakat.

Kata Kunci : Pemberdayaan, ibu rumah tangga, budidaya, tanaman obat keluarga
\end{abstract}

\section{PENDAHULUAN}

Pembangunan adalah suatu proses perubahan yang dilakukan secara kontinu oleh suatu bangsa untuk meningkatkan taraf hidup dan kesejahteraan masyarakatnya. Dalam hal ini potensi perempuan yang tidak terlepas peranannya sebagai ibu rumah tangga merupakan komponen bangsa yang dapat diberdayakan untuk peningkatan kesejahteraan keluarga. Kondisi di lapangan menunjukkan bahwa selama ini pemanfaatan dan pengelolaan sumberdaya perdesaan sebagian besar dilakukan oleh laki-laki, mulai dari kegiatan di bidang pertanian, peternakan, industri kecil dan menengah, koperasi, dan kegiatan lain yang sifatnya kegiatan ekonomi. Padahal perempuan sebagai anggota masyarakat juga mempunyai hak untuk ikut serta dalam pemanfaatan dan pengelolaan sumberdaya perdesaan, meskipun kemungkinan peran perempuan tidak sebesar peran laki-laki.

Kemajuan di berbagai bidang akibat kemajuan ilmu pengetahuan dan teknologi merupakan tantangan besar bagi perempuan untuk senantiasa mampu memanfaatkan dan mengelola lingkungannya. Oleh karena itu diperlukan adanya berbagai program yang dapat dilakukan perempuan dalam rangka peningkatan kesejahteraan keluarga dengan memanfaatkan dan mengelola lingkungan sekitarnya. Hal ini sejalan dengan penelitian yang telah dilakukan Hastuti dan Dyah Respati SS (2009), yang berjudul "Model Pemberdayaan Perempuan Miskin Berbasis Pemanfaatan Sumberdaya Perdesaan Sebagai Upaya Pengentasan Kemiskinan di Kelurahan Limo". Salah satu program yang dapat dilaksanakan oleh perempuan dalam upaya peningkatan 
kesejahteraan keluarga, khususnya di bidang pangan adalah program penanaman dan pemanfaatan Tanaman Obat Keluarga (TOGA). Program ini sekaligus menyikapi menurunnya daya beli masyarakat akibat harga obat yang semakin mahal, sehingga secara tidak langsung 7 berdampak pada menurunnya derajat kesehatan masyarakat.

TOGA adalah tanaman hasil budidaya rumahan yang berkhasiat sebagai obat. Penanaman TOGA dapat di pot atau di lahan sekitar rumah, dan jika lahan yang ditanami cukup luas maka sebagian hasil panen dapat dijual dan menambah pendapatan keluarga. Adapun pemanfaatan TOGA selain sebagai obat, juga dapat dimanfaatkan untuk: (1) penambah gizi keluarga (pepaya, timun, bayam), (2) bumbu atau rempah-rempah masakan (kunyit, kencur, jahe, serai, daun salam), (3) menambah keindahan (mawar, melati, bunga matahari, kembang sepatu, tapak dara, kumis kucing).

Kelurahan Cinere merupakan salah satu kecamatan yang berada di Kota Depok . Umumnya masyarakat di wilayah tersebut masih memiliki lahan pekarangan yang cukup luas, sehingga pemanfaatan dan pengelolaan lingkungan dapat dioptimalkan dengan penanaman TOGA. Oleh karena itu perlu dilakukan pelatihan tentang khasiat TOGA secara ilmiah.

Masyarakat yang telah memiliki pengetahuan tentang khasiat TOGA dan menguasai cara pengolahannya dapat membudidayakan tanaman obat secara individual dan memanfaatkannya sehingga akan terwujud prinsip kemandirian dalam pengobatan keluarga. Selain itu juga dapat dikembangkan menjadi usaha kecil dan menengah di bidang obat-obatan herbal, yang selanjutnya dapat disalurkan ke masyarakat.

Mengingat TOGA sangat bermanfaat untuk kesehatan, maka adanya pemanfaatan sumberdaya perdesaan berupa TOGA dengan melibatkan ibu rumah tangga di Kelurahan Cinere diharapkan mampu mendukung peningkatan kesehatan masyarakat dan sekaligus pemberdayaan perempuan dalam upaya pengentasan kemiskinan di Kelurahan Cinere .Oleh karena itu dipandang perlu bagi Tim Pengabdi untuk melakukan pengabdian kepada masyarakat dengan mengambil judul "Pemberdayaan Ibu Rumah Tangga di Kelurahan Cinere dalam Penanaman dan Pemanfaatan Tanaman Obat Keluarga (TOGA)"

\section{METODE KEGIATAN PKM}

Metode kegiatan pengabdian kepada masyarakat, yaitu:

\section{Ceramah}

Metode ceramah yang dikombinasikan dengan menggunakan laptop dan LCD proyektor digunakan untuk menyampaikan materi tentang:
a. Khasiat TOGA secara ilmiah,
b. Penanaman TOGA, dan
c. Pengolahan TOGA.

Penggunaan metode ini dapat memberikan materi relatif banyak secara padat, cepat, dan mudah.

\section{Demonstrasi}

Metode demonstrasi digunakan untuk menunjukkan suatu proses kerja sehingga memberikan kemudahan bagi peserta pengabdian. Demonstrasi dilakukan oleh tim pengabdi sebagai 
narasumber untuk menyampaikan atau mempraktekkan pengolahan TOGA menjadi bahan minuman.

\section{A. Langkah-Langkah Kegiatan PPM}

Adapun langkah-langkah kegiatan PPM ini melalui tahapan sebagai berikut:

\section{Persiapan}

Persiapan merupakan perencanaan program pengabdian yang meliputi:

a. Koordinasi dengan pihak lokasi pengabdian,

b. Penentuan lahan penanaman Tanaman Obat Keluarga (TOGA)

c. Penetapan waktu pelatihan,

d. Penentuan sasaran dan target peserta pelatihan, dan

e. Perencanaan materi pelatihan.

\section{Pelaksanaan}

Pengabdian masyarakat dilakukan untuk meningkatkan pengetahuan ibu rumah tangga tentang khasiat TOGA secara ilmiah dan tata cara menanam TOGA serta meningkatkan keterampilan dalam mengolah TOGA diberikan kegiatan pelatihan. Pelatihan dilakukan oleh tim pengabdi untuk penyamaan persepsi dengan peserta. Pelatihan dilakukan dengan penyediaan sarana dan prasarana kegiatan pengabdian dalam upaya peningkatan pengetahuan dan keterampilan ibu rumah tangga, meliputi penyampaian makalah tentang aneka jenis tanaman obat-obatan dan khasiatnya, tata cara penanaman tanaman obat yang baik, serta praktek pengolahan tanaman obat menjadi bahan minuman.

\section{B. Faktor Pendukung dan Penghambat}

Kegiatan Faktor pendukung dan penghambat dalam pelaksanaan pengabdian sebagai berikut:

\section{Faktor Pendukung}

a. Kepala Camat yang mendukung pelaksanaan kegiatan pelatihan.

b. Ketua RT dan RW yang membantu kelancaran dan kesuksesan pelaksanaan kegiatan pelatihan.

c. Antusiasme ibu-ibu rumah tangga Kelurahan Cinere sebagai peserta pelatihan.

\section{Faktor Penghambat}

a. Keterbatasan waktu pelaksanaan pelatihan.

b. Keterbatasan pengetahuan ibu rumah tangga tentang pemanfaatan tanaman obat keluarga (TOGA)

\section{HASIL}

Hasil pelaksanaan kegiatan pengabdian dapat diuraikan melalui 2 (dua) tahapan kegiatan, yaitu persiapan dan pelaksanaan. Pada tahap persiapan yang merupakan perencanaan program pengabdian dilakukan kegiatan sebagai berikut:

1. Koordinasi dengan pihak lokasi pengabdian Koordinasi dengan pihak PKK kelurahan Cinere

Pihak PKK mendukung kegiatan pengabdian yang dilakukan oleh Tim dalam rangka memberdayakan ibu-ibu rumah tangga di wilayahnya dan diharapkan mampu mendukung keberadaan Kelurahan Cinere.

2. Penetapan waktu pelatihan 
Pelaksanaan pelatihan berdasarkan kesepakatan dengan Ketua PKK Kelurahan Cinere dilakukan pada hari Jumat, tanggal 7 September 2018.

3. Penentuan sasaran dan target peserta pelatihan

Dari koordinasi dengan Ibu Ketua Pokja II Kelurahan Cinere maka sasaran pelatihan adalah ibu-ibu rumah tangga di RW 12 Kelurahan Cinere, yaitu dengan target peserta pelatihan sebanyak 20 orang.

4. Perencanaan materi pelatihan

Materi pelatihan yang telah direncanakan oleh tim pengabdi meliputi pengetahuan tentang aneka jenis tanaman obat-obatan dan khasiatnya, serta tata cara penanaman tanaman obat yang baik. Tahapan persiapan di atas selanjutnya diikuti dengan tahap pelaksanaan. Pada tahap pelaksanaan program pengabdian dapat diuraikan bahwa:

a. Kegiatan pengabdian "Pemberdayaan Ibu Rumah Tangga di Kelurahan Cinere dalam Pemanfaatan Tanaman Obat Keluarga (TOGA)" dilaksanakan pada hari Jumat, 7 September 2018.

b. Kegiatan pengabdian dihadiri oleh 16 orang peserta yaitu Ibu Kader di RW 12 Kelurahan Cinere.

c. Para peserta cukup senang dan antusias dengan adanya program pengabdian dari tim dosen Prodi Kesehatan Masyarakat berupa Penanaman dan Pemanfaatan TOGA sebagai upaya pemberdayaan ibu-ibu rumah tangga.

d. Materi pelatihan berupa:

a. Pengetahuan tentang aneka jenis tanaman obat-obatan dan khasiatnya,

b. Pengetahuan tentang tata cara penanaman tanaman obat yang baik, serta

c. Praktek pengolahan tanaman obat menjadi bahan minuman (Jahe dan Temulawak), termasuk cara mengemasnya. Semua materi tersebut dapat disampaikan oleh tim pengabdi dengan waktu terbatas.

e. Pada sesi tanya jawab ada beberapa pertanyaan yang diajukan peserta, antara lain: persyaratan apa yang harus dipenuhi agar tanaman obat dapat tumbuh subur, peluang budidaya tanaman obat, dan bagaimana solusi agar tanaman obat yang diolah hasilnya baik dan menarik (tidak gelap/"gosong").

f. Dalam kegiatan pelatihan diberikan beberapa contoh tanaman obat (30 jenis tanaman) untuk dibudidayakan di lokasi pengabdian dan beberapa bentuk olahan dari tanaman obat (berupa serbuk) untuk mengatasi berbagai masalah kesehatan yang dialami masyarakat.

\section{PEMBAHASAN}

Hasil pelaksanaan kegiatan pengabdian dapat diuraikan melalui 2 (dua) tahapan kegiatan, yaitu persiapan dan pelaksanaan. Pada tahap persiapan yang merupakan perencanaan program pengabdian dilakukan kegiatan sebagai berikut:

1. Koordinasi dengan pihak lokasi pengabdian Koordinasi dengan pihak PKK kelurahan Cinere

Pihak PKK mendukung kegiatan pengabdian yang dilakukan oleh Tim dalam rangka memberdayakan ibu-ibu rumah tangga di wilayahnya dan diharapkan mampu mendukung keberadaan Kelurahan Cinere.

2. Penetapan waktu pelatihan

Pelaksanaan pelatihan berdasarkan kesepakatan dengan Ketua PKK Kelurahan Cinere dilakukan pada hari Jumat, tanggal 7 September 2018.

3. Penentuan sasaran dan target peserta pelatihan 
Dari koordinasi dengan Ibu Ketua Pokja II Kelurahan Cinere maka sasaran pelatihan adalah ibu-ibu rumah tangga di RW 12 Kelurahan Cinere, yaitu dengan target peserta pelatihan sebanyak 20 orang.

4. Perencanaan materi pelatihan

Materi pelatihan yang telah direncanakan oleh tim pengabdi meliputi pengetahuan tentang aneka jenis tanaman obat-obatan dan khasiatnya, serta tata cara penanaman tanaman obat yang baik.

Tahapan persiapan di atas selanjutnya diikuti dengan tahap pelaksanaan. Pada tahap pelaksanaan program pengabdian dapat diuraikan bahwa:

a. Kegiatan pengabdian "Pemberdayaan Ibu Rumah Tangga di Kelurahan Cinere dalam Pemanfaatan Tanaman Obat Keluarga (TOGA)" dilaksanakan pada hari Jumat, 7 September 2018.

b. Kegiatan pengabdian dihadiri oleh 16 orang peserta yaitu Ibu Kader di RW 12 Kelurahan Cinere.

c. Para peserta cukup senang dan antusias dengan adanya program pengabdian dari tim dosen Prodi Kesehatan Masyarakat berupa Penanaman dan Pemanfaatan TOGA sebagai upaya pemberdayaan ibu-ibu rumah tangga.

d. Materi pelatihan berupa:

1) Pengetahuan tentang aneka jenis tanaman obat-obatan dan khasiatnya,

2) Pengetahuan tentang tata cara penanaman tanaman obat yang baik, serta

3) Praktek pengolahan tanaman obat menjadi bahan minuman (Jahe dan Temulawak), termasuk cara mengemasnya. Semua materi tersebut dapat disampaikan oleh tim pengabdi dengan waktu terbatas.

e. Pada sesi tanya jawab ada beberapa pertanyaan yang diajukan peserta, antara lain: persyaratan apa yang harus dipenuhi agar tanaman obat dapat tumbuh subur, peluang budidaya tanaman obat, dan bagaimana solusi agar tanaman obat yang diolah hasilnya baik dan menarik (tidak gelap/"gosong").

f. Dalam kegiatan pelatihan diberikan beberapa contoh tanaman obat (30 jenis tanaman) untuk dibudidayakan di lokasi pengabdian dan beberapa bentuk olahan dari tanaman obat (berupa serbuk) untuk mengatasi berbagai masalah kesehatan yang dialami masyarakat.

\section{KESIMPULAN}

Masyarakat yang telah memiliki pengetahuan tentang khasiat TOGA dan menguasai cara pengolahannya dapat membudidayakan tanaman obat secara individual dan memanfaatkannya sehingga akan terwujud prinsip kemandirian dalam pengobatan keluarga. Selain itu juga dapat dikembangkan menjadi usaha kecil dan menengah di bidang obat-obatan herbal, yang selanjutnya dapat disalurkan ke masyarakat.

\section{SARAN}

Saran yang dapat diberikan kepada masyarakat wilayah Kelurahan Cinere adalah sebagai berikut :

a. Untuk meningkatkan pengetahuan masyarakat di wilayah kerja Kelurahan Cinere, sebaiknya diadakan penyuluhan tentang pengobatan dengan menggunakan tanaman obat untuk alternatif terapi.

b. Penggunaan tanaman obat sebaiknya tidak sembarangan, melainkan melalui konsultasi dengan tenaga medis terlebih dahulu. 
c. Pembudidayaan TOGA yang dilakukan di wilayah ini dapat ditingkatkan dengan menggunakan rumah model yang membudidayakan TOGA misalnya di puskesmas ataupun di rumah tokohtokoh masyarakat.

\section{DAFTAR PUSTAKA}

Anonim. 2005. Teknik Budidaya Tanaman Obat. Kabupaten Majene: Satuan Kerja Pembina dan Pengembangan Hortikultura.

Departemen Kesehatan RI. 1983. Pemanfaatan Tanaman Obat. Edisi III. Jakarta: Direktorat Jenderal Pengawasan Obat dan Makanan.

Fauziah Muhlisah. 2000. Taman Obat Keluarga (TOGA). Jakarta: Penebar Swadaya.

Hastuti dan Dyah Respati SS. 2009. Model Pemberdayaan Perempuan Miskin Berbasis Pemanfaatan Sumberdaya Perdesaan Sebagai Upaya Pengentasan Kemiskinan di Perdesaan Lereng Merapi Selatan. Laporan Akhir Hibah Bersaing. Yogyakarta: UNY.

Ridwan. 2007. Pemanfaatan Tanaman Obat Keluarga. Jakarta: Pusat Perbukuan Departemen Pertanian.

Supriyanto. 2006. Proses Pengolahan Tanaman Obat. Jakarta: Tim Lentera.

Tukiman. 2004. Pemanfaatan Tanaman Obat Keluarga (TOGA) Untuk Kesehatan Keluarga. Bagian Pendidikan Kesehatan dan Ilmu Perilaku Fakultas Kesehatan Masyarakat Universitas Sumatera Utara. USU: Digital Library. 